\title{
The C/EBP $\beta$ transcription factor regulates epithelial cell proliferation and differentiation in the mammary gland
}

\author{
Gertraud W. Robinson, ${ }^{2}$ Peter F. Johnson, ${ }^{1}$ Lothar Hennighausen, and Esta Stemeck ${ }^{1}$ \\ Laboratory of Genetics and Physiology, National Institute of Diabetes, Digestive and Kidney Diseases, N ational Institutes \\ of Health (NIH), Bethesda, M aryland 20892-1812 USA; ${ }^{1}$ Eukaryotic Transcriptional Regulation Group, ABL-Basic Research \\ Program, N ational Cancer Institute, Frederick Cancer Research and Development Center, Frederick, Maryland $21702-1201$ USA
}

\begin{abstract}
Studies of C/EBP $\beta$-deficient mice have demonstrated a pivotal role for this transcription factor in hematopoiesis, adipogenesis, and ovarian function. Here we show that C/EBPB is also essential for nomal development and function of the mammary gland. Ductal morphogenesis in virgin C/EBP $\beta$-deficient mice was disnupted, with ducts displaying reduced growth and branching. To distinguish whether the effect of C/EBP deficiency on mammary epithelium is indirect or cell autonomous, we performed ovarian and mammary gland transplants. Transplants of wild-type ovaries into mutant females partially restored ductal morphogenesis during puberty but failed to support mammopoiesis during pregnancy. At term, mutant mice harboring wild-type ovaries exhibited reduced alveolar proliferation and impaired epithelial cell differentiation, including a complete absence of milk protein expression. Mammary gland transplant experiments demonstrated that development of $\mathrm{C} / \mathrm{EBP} \beta$-deficient epithelium was defective within a wild-type stroma and host background. Cell proliferation during pregnancy was reduced and differentiation, as measured by the activity of milk protein genes, was inhibited. However, wild-type epithelium developed in a C/EBP $\beta$-deficient stroma. Thus, C/EBP $\beta$ plays an essential, cell autonomous role in the proliferation and differentiation of mammary secretory epithelial cells and is required for the activation of milk protein genes.
\end{abstract}

[Key Words: Mammopoiesis; ductal morphogenesis; alveoli; milk proteins; gene deletion]

Received March 4, 1998; accepted in revised form April 14, 1998.

The C/EBPs (CCAAT/enhancer binding proteins) are a family of transcription factors with diverse regulatory functions. $\mathrm{C} / \mathrm{EBP} \alpha, \beta$, and $\delta$ are expressed in partially overlapping patterns in many organs (C ao et al. 1991; Williams et al. 1991), whereas $\mathrm{C} / \mathrm{EBP} \epsilon$ is restricted to cells of the myeloid lineage (Yamanaka et al. 1997b). $\mathrm{C} / \mathrm{EBP} \gamma(\mathrm{Ig} / \mathrm{EBP})$ is thought to have inhibitory functions (Cooper et al. 1995) and is expressed at low levels in most tissues and cell types (Roman et al. 1990). In cell culture experiments, $\mathrm{C} / \mathrm{EBP} \alpha$ and $\mathrm{C} / \mathrm{EBP} \beta$ are potent regulators of cell proliferation and differentiation in hepatocytes, adipocytes and myeloid cells Johnson and Williams 1994).

The creation of mice with targeted disruptions of c/ ebp genes has led to a more detailed understanding of the biological functions of the C/EBP proteins. Mice lacking $\mathrm{C} / \mathrm{EBP} \alpha$ die shortly after birth because of reduced glycogen storage in the liver (Wang et al . 1995) and display impaired devel opment of granulocytes (Zhang et

${ }^{2}$ Corresponding author.

E-MAIL gertraur@bdg10.niddlk.nih.gov; FAX (301) 496-0839. al. 1997). C/EBP $\epsilon$ null animals are viable but fail to produce mature neutrophils and eosinophils, and older mice develop myelodysplasia (Yamanaka et al. 1997a). C/ EBP $\beta$-deficient mice exhibit multiple immune deficiencies (Screpanti et al. 1995; Tanaka et al. 1995), as well as defective differentiation of adipocytes (Tanaka et al. 1997). In addition, C/EBP $\beta$-null females are sterile because of impaired ovulation and the absence of corpora lutea resulting from a block during granulosa cell differentiation (Sterneck et al. 1997). Fertility in these mice can be restored by implanting wild-type ovaries. However, their offspring die shortly after birth and, despite apparently normal suckling behavior, the pups do not have milk in their stomachs (Sterneck et al. 1997). These findings suggested that the C/EBP $\beta$ mutation may also affect mammary gland development or function.

Several c/ebp genes expressed in the mammary gland are devel opmental ly regulated during pregnancy and lactation. $\mathrm{C} / \mathrm{EBP} \alpha$ and $\mathrm{C} / \mathrm{EBP} \beta \mathrm{mRN}$ As are expressed in the mammary gland of virgin animals. C/EBP $\alpha$ levels do not change significantly during pregnancy and lactation, whereas C/EBP $\beta$ mRN A levels are induced during preg- 
nancy, decline slightly at midlactation, and increase again within $48 \mathrm{hr}$ of the onset of involution. C/EBP $\delta$ mRNA expression is generally low but increases dramatically at the onset of involution (Gigliotti and DeWille 1998). C/EBP $\delta$ expression also correlates with growth arrest of mammary epithelial cells in culture (O'Rourke et al. 1997).

Development of the mammary gland proceeds in distinct stages (Imagawa et al . 1994) and is controlled by an interplay of steroid and peptide hormones (Topper and Freeman 1980). Although a rudi mentary anlage is formed in the embryo, extensive morphogenesis of the gland commences with puberty and the secretion of ovarian steroid hormones. This period is characterized by rapid elongation of the epithelial ducts, which penetrate the mammary fat pad. In mature virgin mice the fat pad is filled with evenly spaced primary ducts from which secondary ducts and smal ler si de branches emanate. Further mammary development is induced during pregnancy under the influence of prolactin and placental hormones. During this period, rapid cell proliferation takes place that leads to formation of secretory alveoli, terminal differentiation of secretory al veolar cells, and synthesis of large amounts of milk proteins. Expression of milk proteins is initiated in a specific temporal sequence (Robinson et al. 1995). WDN M 1, a secreted protein whose function is not known, is produced first and its mRN A can be detected easily at 10 days of pregnancy. Two days later mRNA for $\beta$-casein becomes detectable, whereas the whey acidic protein (WAP) gene is expressed at detectable levels from day 15 onwards. These mRNAs thus serve as markers for the differentiation state of the epithelium (Robinson et al. 1995).

In the present study we have examined mammary gland development in C/EBP $\beta$-deficient mice, and show that glandular development is impaired in virgin, pregnant, and lactating animals. We have also used ovarian and mammary gland transplantation experiments to assess whether these defects originate from the mammary epithelium or stromal compartment, or from possible effects of altered ovarian hormonal signals. Both experimental approaches mimicked unique physiological situations and revealed that functional mammary development requires the presence of C/EBP $\beta$ in the mammary epithelium itself. Our studies demonstrate that mammary epithelial cells require C/EBP $\beta$ for proper prol iferative and morphogenic responses during mammary gland development, and for their differentiation to secretory cells during pregnancy as demonstrated by the complete absence of milk protein expression in C/EBP $\beta$-deficient mammary glands.

\section{Results}

Expression of $\mathrm{C} / \mathrm{EBP} \beta$ during normal mammary gland development

The steady-state mRN A levels corresponding to different C/EBP isoforms were measured at various stages of mammary gland development (Fig. 1). Expression of

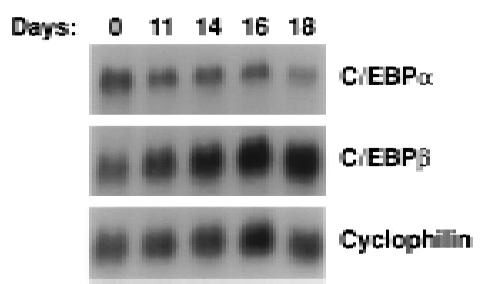

Figure 1. Expression profile of C/EBP RNA during mammary gland development. Northern blot analysis of total RNA from mammary glands of virgin and pregnant wild-type mice at various stages of gestation. The blot was hybridized sequentially with probes for the indicated genes.

$\mathrm{C} / \mathrm{EBP} \alpha$ was highest in the virgin state and was maintained at a slightly lower level throughout pregnancy. In contrast, expression of C/EBP $\beta$ was lowest in the virgin and increased throughout pregnancy. Whereas C/EBP $\beta$ expression has been described in several transformed or immortalized mammary epithelial cells in culture as well as in mammary epithelial tumors (Raught et al. 1995, 1996; O'Rourke et al. 1997), its role in adipose tissue development and function is also well characterized (Tanaka et al. 1997 and references therein). Therefore, the observed signal may be derived from both components of the gland. The cyclophilin signal served as a loading control.

\section{Aberrant mammary gland development in $\mathrm{C} / \mathrm{EBP} \beta$-deficient virgin mice}

Extensive development of the mammary gland commences at three weeks of age when mice reach puberty. In C/EBP $\beta$-deficient mice a delayed ductal outgrowth was observed as early as 3 weeks of age (Fig. 2). The extent of ductal outgrowth is best evaluated from the position of the terminal end buds in relationship to the mammary lymph node. The lymph nodelies distal to the nipple from which the mammary ductal tree originates. In three-week-old wild-type and hemizygous mice the ducts had el ongated close to the lymph node (Fig. 2A). In contrast, the mammary ducts were shorter in C/EBP $\beta$ deficient mice and had not reached the lymph node (Fig. 2B). The terminal end buds, which are club-shaped epithelial thickenings, are the sites of most rapid cell proliferation and ductal elongation at the distal ends of growing ducts. They have a characteristic architecture with central body cells surrounded by a distinctive layer of cap cells. In both control and C/EBP $\beta$-deficient mice the histology of the terminal end buds appeared normal (data not shown). In mature wild-type mice, extensively branched ducts occupy the mammary fat pad (Fig. 2G). In contrast, ductal morphogenesis was severely disturbed in the majority of mature mutant mice. The ducts were distended and had very few side branches. The degree of failure of normal ductal morphogenesis and branching varied among the eight animals that were examined between 2 and 6.5 months of age (Fig. 2C-E). Such variation in penetrance of the phenotype was also observed in the 

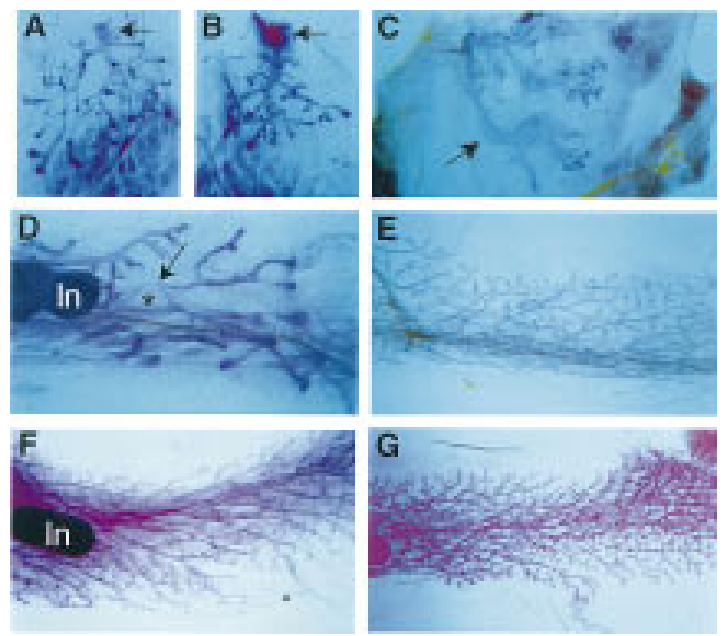

Figure 2. Whole mount analysis of ductal morphogenesis in virgin mice. A difference in growth was al ready detected in 3-week-old females. The ductal tree in wild-type mice (A) is larger than in C/EBP $\beta$-deficient mice (B). The arrow points to the nipple. (C) An example of extremely disturbed ductal development in a 2-month-old C/EBP $\beta$-deficient mouse. The primary ducts appear like large tubes and lack secondary branches $(\rightarrow)$. (D) A 3.5-month-old C/EBP $\beta$-deficient mouse with very irregular ducts. $\mathrm{N}$ ote the expanded balloon-like duct indicated by the asterix. (E) A 5-month-old C/EBP $\beta$-deficient mouse with almost normal primary ducts that have sparse secondary branches. (F) A 4-month-old C/EBP $\beta$-deficient mouse with ovary transplant. Ovarian hormones induce formation of secondary side branches. (G) A 3-month-old wild-type mouse with fully devel oped ductal system. Magnification in A-D, 4× E-G, 13x (In) Lymph node.

accumulation of fat and overall wasting of C/EBP $\beta$-deficient animals (Tanaka et al. 1997).

\section{Mammary gland development in C/EBP $\beta$-deficient} mice carrying wild-type ovaries

Since ovarian function is disrupted in C/EBP $\beta$-deficient mice (Sterneck et al. 1997), we asked whether the perturbation of mammary development could be rescued by wild-type ovary transplants. Ductal morphogenesis in four mature virgins, which received wild-type ovaries at the age of 3-4 weeks, was partially restored (Fig. 2F). The peri pheral ducts had more side branches than the ducts in the center. This result demonstrates that the impaired development of the mammary gland in virgin C/EBP $\beta$ null mice is in part due to the lack of normal ovarian function, and confirms the importance of ovarian steroids in pubertal mammary gland development.

To evaluate whether C/EBP $\beta$ only affects ductal morphogenesis or also controls al veolar development, we studied mammary structures in pregnant mice (Fig. 3). At day 18 postcoitum, wild-type glands had undergone extensive lobul oalveol ar growth and were filled with enlarged alveoli that contain milk (Fig. 3B,D). In contrast, mammary gland devel opment in C/EBP $\beta$-deficient mice with wild-type ovaries (Fig. $3 A, C$ ) resembled that of wild-type animals at early pregnancy (not shown). Two distinct lesions were observed. Alveolar density in the fat pad was severely curbed and little or no alveolar differentiation on a histological level was observed (Fig. $3 A)$. Specifically, secretory vesicles and fat gl obules were seen in the cytoplasm of wild-type secretory cells (Fig. 3D) but were absent in the null mice (Fig. 3C). These results demonstrate that alveolar development and differentiation of epithelial cells is severely impaired in pregnant $C / E B P \beta$-deficient mice with wild-type ovary transplants.

Devel opment of C/EBP $\beta$-deficient mammary epithelium in wild-type hosts

To investigate whether the mammary gland phenotype was caused by impaired epithelial cells or indirect influences of systemic defects we performed mammary epithelial transplants. Surgical removal of the area between the nipple and the fat pad at three weeks of age leaves a fat pad free of the endogenous mammary epithelium. A small piece of mammary epithelium from another syngeneic animal can be implanted and will develop. After several weeks an entire epithelial tree will grow from the transplant and penetrate the host fat pad ( $\mathrm{DeO}$ me et al. 1959). One fat pad per mouse received a small piece of mutant epithelium, whereas the contralateral fat pad hosted a control transplant from a wild-type or hemizygous animal. Thus, the transplanted epithelia are exposed to normal circulating hormone levels and wildtype stroma throughout puberty and pregnancy. Trans-

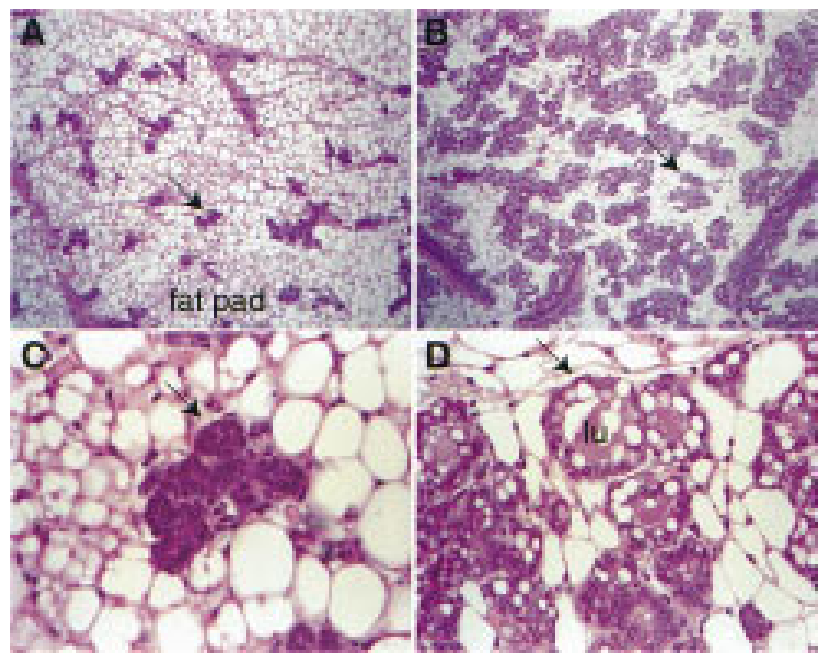

Figure 3. Alveolar devel opment in C/EBP $\beta$-deficient mice carrying a wild-type ovary transplant. At day 18 of pregnancy the mammary gland of C/EBP $\beta$-deficient mice $(A)$ is sparsely filled with underdeveloped alveoli $(\rightarrow)$. No signs of secretory differentiation are visible at high magnification (C). The mammary gland of a wild-type mouse (B) is filled with differentiated alveoli $(\rightarrow)$. At high magnification, the expanded lumen (lu) and fat globules are visible (D). 


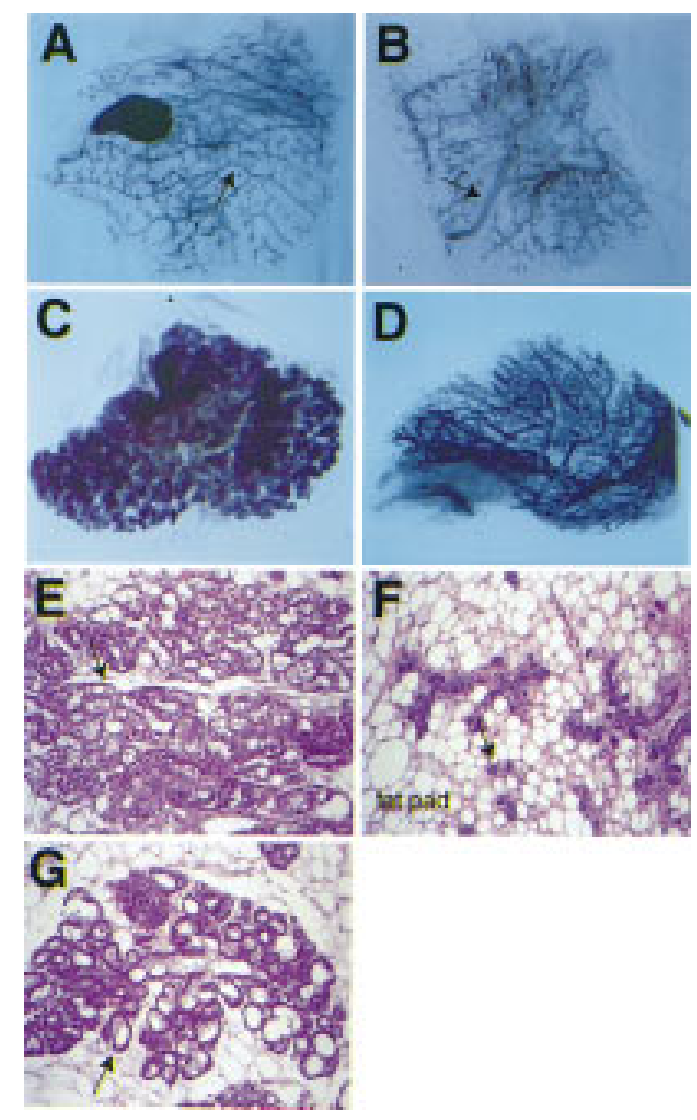

Figure 4. Development of $C / E B P \beta$-deficient epithelium in wild-type stroma. Mammary epithelia from hemizygous $(A, C)$ and $C / E B P \beta$-deficient $(B, D)$ animals were transplanted into fat pads of 3-week-old wild-type mice and harvested from virgin mice 8 weeks later $(A, B)$ or after the mice had delivered a litter $(C, D)$. N ote the thick primary ducts $(\rightarrow)$ and irregular side branching in the $\mathrm{C} / \mathrm{EBP} \beta$-deficient transplant in the virgin stage (B). At term, C/EBP $\beta$-deficient epithelia (D) have underdeveloped small al veoli, whereas the heterozygous transplant (C) fills the stroma with fully devel oped al veoli. (E) Histological section of gland shown in C. (F) Histological section of gland shown in D. (G) Section through endogenous gland of host animal at term. Arrows point to alveoli.

plants were harvested from 11 mice after 4 or 8 weeks and whole mounts were prepared to evaluate the shape and extent of epithelial outgrowth. Of the seven C/ EBP $\beta$-deficient epithelia that were recovered from the wild-type fat pads, all but one, which looked normal, produced ducts that were thicker (Fig. 4B) than those produced by wild-type controls (Fig. 4A) and only three had filled the fat pad entirely. This result demonstrates that requirement for $C / E B P \beta$ in the virgin mammary gland is cell autonomous and epithelia from C/EBP $\beta$ deficient mice maintain their abnormal growth characteristics even when they develop in a wild-type host under the influence of functional ovaries.

To analyze the development of the epithelial transplants in response to pregnancy hormones, 17 wild-type hosts were mated and their mammary glands were har- vested for whol e mounts and RN A isolation within $12 \mathrm{hr}$ after the animals delivered a litter. Again, the developmental state of the C/EBP $\beta$-deficient epithelium of term mice (Fig. 4D) resembled that of wild-type animals at early pregnancy (not shown). The C/EBP $\beta$-deficient alveol $\mathrm{i}$ were underdevel oped as compared to control wildtype animals or transplanted wild-type epithelia (Fig. 4C). In histological sections the mutant alveoli appeared small, the lumina were not expanded, and the epithelial cells showed no signs of secretory activity (Fig. 4F), whereas fully differentiated cells were found in transplanted hemizygous epithelium (Fig. 4E) and the endogenous $\mathrm{gl}$ and of the host (Fig. 4G). In summary, these data demonstrate that epithelia from C/EBP $\beta$-deficient mice maintain their abnormal growth characteristics even when they are embedded in a wild-type fat pad and develop in a wild-type host under the influence of functional ovaries, suggesting that the $C / E B P \beta$ mutation perturbs epithelial cells directly.

\section{Expression of milk protein genes in C/EBP $\beta$-deficient} epithelium

To characterize the state of epithelial cell differentiation and to begin to identify the deficiency of mutant epithelium at the molecular level, we analyzed the expression of several milk protein genes (Fig. 5). The $\beta$-casein and WAP genes are highly expressed in wild-type mice at day 18 of pregnancy or at day 3 of lactation. However, no

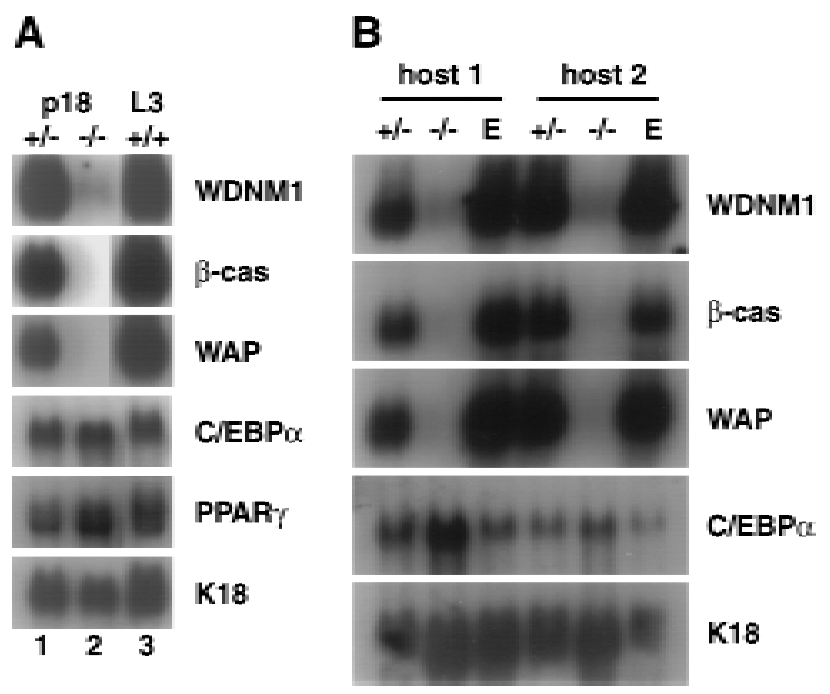

Figure 5. Gene expression in pregnant and lactating tissues. (A) N orthern blot analysis of total RN A from mammary glands of hemizygous (lane 1) and C/EBP $\beta$ null mice with wild-type ovaries (lane 2 ) at day 18 of pregnancy. Lane 3 represents RN A from a wild-type mouse on day 3 of lactation. The blot was hybridized sequentially with probes for the indicated genes. (B) $\mathrm{N}$ orthern blot analysis of total RNA derived from mammary glands of two wild-type host animals at term with epithelial transplants from a hemizygous donor (lane 1) or a C/EBP $\beta$ null donor (lane 2). Lane 3 represents RN A from an unoperated endogenous gland. The blot was analyzed as described in A. 
expression of $\beta$-casein or WAP mRNA was detected in mammary tissue from mutant mice at day 18 of pregnancy (Fig. 5A). Expression of WDNM 1 was barely detectable and at least 100-fold lower than in wild-type mice (Fig. 5A). As a control for the contribution of epithelium to the RN A samples we assessed the expression of the epithelial cell specific keratin18 gene (Singer et al. 1986) (Fig. 5A). Similar results were obtained when mammary glands from wild-type hosts with C/EBP $\beta$-deficient epithelial transplants were analyzed (Fig. 5B). Even at long exposures, no expression of $\beta$-casein and WAP was seen (not shown). Thus, the bi ochemically undifferentiated phenotype of mutant glands agrees with the morphologically immature appearance of $C / E B P \beta-$ deficient alveoli.

We also analyzed whether the expression of $C / E B P \alpha$ was altered in the absence of $C / E B P \beta . C / E B P \alpha \operatorname{mRN} A$ levels in wild-type mammary glands were significantly lower than C/EBP $\beta$ and did not change significantly during pregnancy (Fig. 1; Gigliotti and DeWille 1998). The majority of the transcripts is likely derived from the adipose tissue (Tanaka et al. 1997). In the mammary glands of $\mathrm{C}$ /EBP $\beta$-deficient pregnant mice, as well as in glands of mutant epithelium in wild-type hosts, $\mathrm{C} / \mathrm{EBP} \alpha$ mRN A was readily detectable and comparable to the levels detected in control tissue. Similar expression levels for PPAR 2 , a marker gene for adipocytes, were also found in wild-type and $C / E B P \beta$-deficient glands (Fig. $5 A, B)$. Thus, the $C / E B P \beta$ mutation does not affect the expression of the related $\mathrm{C} / \mathrm{EBP} \alpha$ gene or a stroma-specific gene.

\section{Development of wild-type epithelium}

in $C / E B P \beta$-deficient stroma

$\mathrm{C} / \mathrm{EBP} \beta$ is required for the differentiation of adipocytes (Tanaka et al. 1997) and it is well known that mammary epithelial development depends on interaction with appropriate mesenchymal signals (Robinson and Hennighausen 1997). Therefore, we asked whether the $C / E B P \beta$-deficient fat pad contributed to the mammary gland phenotype of mutant mice. To this aim, wild-type epithel ia were transplanted into cleared fat pads of either wild-type or C/EBP $\beta$-deficient animals. The fat pads containing the epithelial implants were then transplanted into wild-type hosts to el iminate any genotypespecific systemic effects. The development of wild-type epithelium in three out of three $C / E B P \beta$-deficient fat pads harvested after 8 weeks was indistinguishable from that in wild-type fat pads (Fig. 6A,B). To evaluate the influence of the stroma on alveolar development, four hosts were mated and mammary tissues were analyzed immediately after parturition. Extensive Iobuloal veolar development of wild-type epithelium took place in both wild-type and C/EBP $\beta$-deficient fat pads (Fig. 6C,D). From these observations we conclude that the absence of $\mathrm{C} / \mathrm{EBP} \beta$ from the stromal compartment does not influence ductal el ongation and branching during puberty or terminal differentiation of secretory epithelial cells.

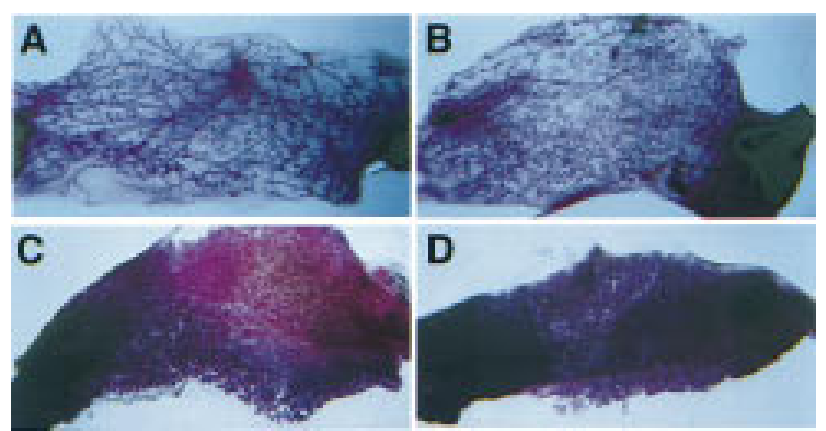

Figure 6. Development of wild-type epithelium in C/EBP $\beta$ deficient stroma. Development of transplanted wild-type epithelia at virgin stage $(A, B)$ and at term $(C, D)$ is the same in wild-type stroma $(A, C)$ and in $C / E B P \beta$-deficient stroma $(B, D)$.

Cell proliferation is reduced in C/EBP $\beta$-deficient mammary epithelium

The impaired development of C/EBP $\beta$-deficient epithelial cells, specifically their reduced density in the mammary fat pad, could be the result of decreased proliferation rate and/or increased rate of apoptosis. To distinguish between these possibilities we injected wild-type mice carrying epithelial transplants with BrdU at different stages of pregnancy. BrdU incorporation as a measure of epithelial cell proliferation was determined at days 6 , $9,11,14$, and 16 of pregnancy (Fig. 7A). Cell proliferation was lower in $\mathrm{C} / \mathrm{EBP} \beta$-deficient epithelia throughout pregnancy. It was significantly reduced at day 6 of pregnancy to only $40 \%$ of the rate seen in wild-type mice. It remained lower until day 14 and was significantly re duced again on day 16. Adjacent sections were used for TUNEL analysis to determine the number of apoptotic cells. Though not statistically significant, the mammary epithelial apoptotic index in early pregnancy was lower in C/EBP $\beta$-deficient mice than in controls but increased from day 11 on (Fig. 7B). These results demonstrate that induction of increased epithelial cell proliferation in early pregnancy and proliferation at late pregnancy stages are impaired in the absence of C/EBP $\beta$.

\section{Discussion}

Mammary gland development during puberty, pregnancy, and lactation is regulated by the intricate interaction of the female endocrine system, the mammary gland epithelium, and stroma. The relevance of distinct genetic pathways for functional mammary gland development has been illustrated in mice with targeted mutations in genes from these pathways (for review, see Hennighausen and Robinson 1998). Using such mouse models it was possible to link the function of specific proteins to distinct stages of postnatal mammary development. Whereas some gene products, such as the prolactin receptor (PRLR) (Ormandy et al. 1997), the Stat5a transcription factor (Liu et al. 1997), or the LAR phosphatase (Schaapveld et al. 1997), control late stages of 
Figure 7. Cell proliferation and apoptosis rates in C/EBP $\beta$-deficient mammary epithelium during pregnancy. At the indicated stages of pregnancy mice bearing contralateral $\mathrm{C} / \mathrm{EBP} \beta$-deficient and control mammary epithelial transplants were injected with BrdU and sacrificed $2 \mathrm{hr}$ later. BrdU labeled nuclei were detected by immunostaining and apoptotic nuclei were stained by TUNEL. Between 6000 and 9000 nuclei were counted and the percentage of labeled cells was determined. The mean \pm standard deviations were calculated and compared by $\mathrm{T}$ test. $\left(^{*}\right) \mathrm{A} \mathrm{P}$ value of $\varangle 0.001$. Wild-type (open bars) and $\mathrm{C} / \mathrm{EBP} \beta$-deficient (filled bars) transplants.

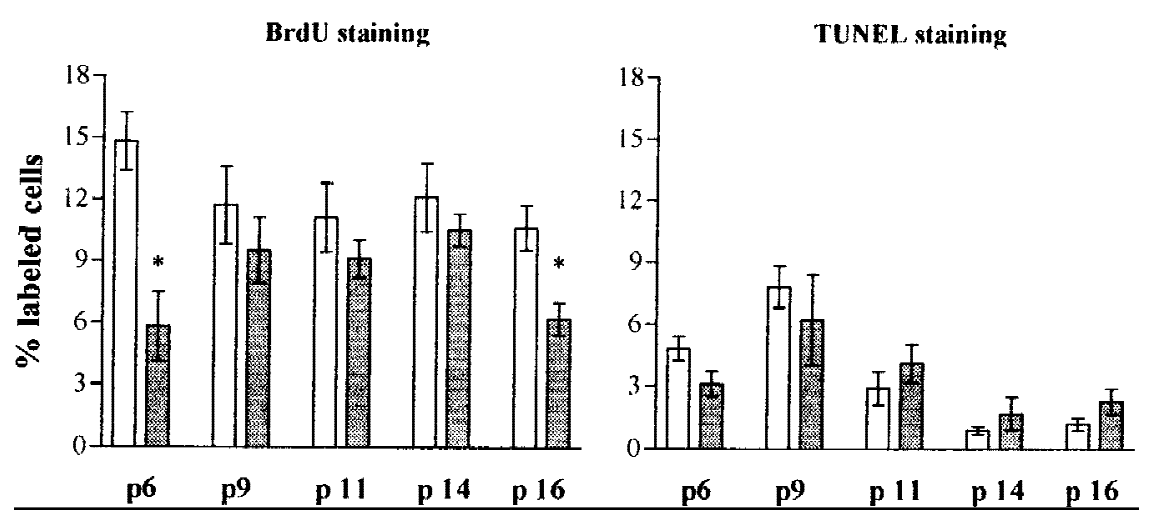

alveolar proliferation and differentiation during pregnancy, others, such as the progesterone receptor (PR) (Lydon et al. 1995; Humphreys et al. 1997) and the estrogen receptor-al pha (ER) (Boccinfuso and Korach 1997; Cunha et al. 1997), are required during puberty and early pregnancy. In addition to steroid and peptide receptors, cell cycle regulators and transcription factors control alveolar development. The absence of cyclin D1 (Fantl et al. 1995; Sicinski et al. 1995) and a-myb (T oscani et al. 1997) causes severe underdevelopment of alveoli at term that has histological resemblance to the defect in C/EBP $\beta$ deficient mice. $C / E B P \beta$ has now emerged as a critical component in the control of both proliferation and early stages of differentiation. The requirement for $C / E B P \beta$ is epithel ial cell autonomous and in the absence of C/EBP $\beta$ only limited proliferation of epithelial cells occurs and the differentiation program leading to a functional gland is not executed (Fig. 8). Thus, we propose that C/EBP $\beta$ partici pates in hormonal signal ing cascades whose endpoint is the lactating mammary gland.

\section{Systemic vs. mammary intrinsic effects}

The mammary gland defect observed in C/EBP $\beta$-deficient mice raised the possibility of two distinct mechanisms. In one, ductal morphogenesis depends on the presence of C/EBP $\beta$ in mammary tissue. In the other, ductal development is dependent on secondary systemic signals that are disrupted by the lack of C/EBP $\beta$ in endocrine tissues. Since C/EBP $\beta$-deficient mice display severely impaired reproductive functions (Sterneck et al. 1997), it was necessary to dissect the role(s) of C/EBP $\beta$ within the mammary gland from those imposed indirectly through ovarian or other signals. Using ovarian transplants, with the aim of restoring physiological hormone levels, we could demonstrate that the defects in ductal morphogenesis observed in mature virgins are partly of secondary nature and caused by nonfunctional ovaries. Impaired ductal outgrowth and branching has al so been observed in mice deficient in the estrogen (Boccinfuso and Korach 1997) or progesterone receptor (Lydon et al. 1995; Humphreys et al. 1997). This corroborates the ovarian component of the C/EBP $\beta$ defect. Al- though wild-type ovary transplants allow pregnancy to occur in otherwise sterile mutant females, the development of the mammary gland is still severely impaired with only limited growth and a complete absence of milk production. Thus, the inability of C/EBP $\beta$-deficient females to sustain their pups postpartum is primarily caused by mammary gland defects and not simply by impaired maternal behavior or development of the pups.

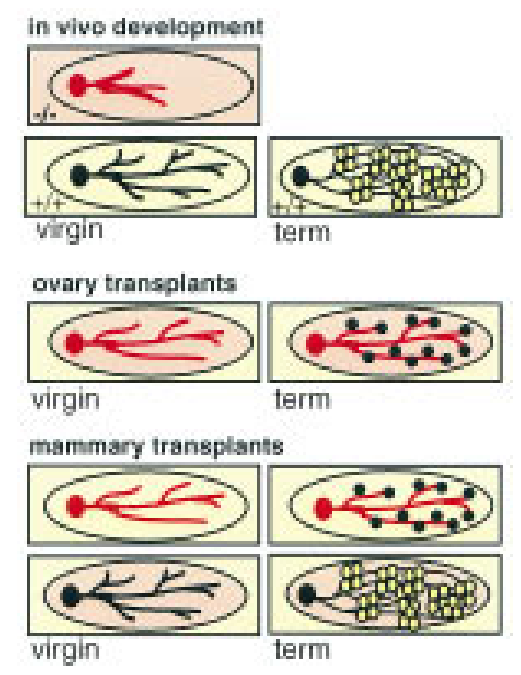

Figure 8. Summary of transplantation results. $C / E B P \beta$-deficient mammary glands display irregular ductal development in virgin glands. In contrast, in wild-type virgins the fat pads are interlaced with regular ducts with small side branches. At term the wild-type gland is filled with secretory alveoli that produce milk (open white circles). When $\mathrm{C} / \mathrm{EBP} \beta$-deficient mice receive an ovarian transplant ductal morphogenesis in virgins resembles more the wild-type phenotype. However, at term the $C / E B P \beta$-deficient glands are sparsely filled with small underdeveloped alveoli that are unable to produce milk (black full circles). Development of C/EBP $\beta$-deficient epithelia in wildtype fat pads is inhibited and cannot be rescued by the wild-type stroma. Wild-type epithelium is able to develop functional alveoli also in $C / E B P \beta$-deficient stroma. C/EBP $\beta$-deficient epithelium (red), C/EBP $\beta$-deficient stroma (pink), wild-type epithelium (black), wild-type stroma (yellow). 
However, C/EBP $\beta$ is also expressed in other organs, such as the adrenal gland (E. Sterneck, unpubl.), the placenta (Chen et al . 1995), and possibly the pituitary (Wegner et al. 1992), which are important for the development of the lactating mammary gl and. Thus, we cannot rule out that other hormonal defects of the mutants are in part responsible for the impaired development of the mammary gland.

The development of the mammary gland depends on coordinated communication between epithelial and stromal cells (Daniel and Silberstein 1987). Because C/EBP $\beta$ is critical for the development and differentiation of adipose tissue (Tanaka et al. 1997), it was important to address the contribution of the mutant stroma to the mammary gl and phenotype. Our transpl ant experiments demonstrated that the mutant mammary gland fat pad can support normal development and differentiation of wildtype mammary epithelia (Fig. 8). Thus, we have rul ed out the stromal component as a leading cause of deficient mammary gland development in $\mathrm{C} / \mathrm{EBP} \beta$ mutant mice. All of these data establ ish that C/EBP $\beta$ deficiency in the epithelial cell is the cause of the impaired mammary gland devel opment in C/EBP $\beta$ mutant mice. Transplant experiments established that functional $C / E B P \beta$ is required in the mammary epithelial cell proper. In summary, our data show that C/EBP $\beta$ deficiency in the epithelial cells is the primary cause of the perturbed mammary gland development.

\section{Putative C/EBP $\beta$ signaling pathways}

Experimental evidence from a variety of cell culture systems has led to the notion that C/EBP $\beta$ participates in cellular responses to many different extracellular signals (for review, see Johnson and Williams 1994). Mammary gland devel opment is controlled by the systemic steroid hormones estrogen and progesterone in conjunction with systemic peptide hormones, including EGF and prolactin (Prl), and paracrine growth regulators (Topper and Freeman 1980; Hennighausen and Robinson 1998). Therefore, we suggest that $C / E B P \beta$ is required for epithelial cells to recognize hormonal signals and/or to execute programs initiated by extracellular cues. C/EBP $\beta$ may well be the mediator of any individual signaling pathway or a funnel for several pathways. In the future, cultures of epithelial cells and analyses of their responses to various signals may give insight into the specific molecular mechanisms underlying the mammary gland phenotype.

At this point, no genuine upstream signals or downstream targets of C/EBP $\beta$ have been identified in vivo. However, a comparison of the morphological and biochemical characteristics of mammary tissue from $\mathrm{C}$ / EBP $\beta$-null mice with those of other engineered mouse mutants al ready sheds some light onto putative suspects. Disabling the Prl and JAK2/Stat5a pathway inactivates late stages of mammary gland development and terminal differentiation is not obtained (Liu et al. 1997; Ormandy et al. 1997). However, extensi ve alveol ar structures partially fill the fat pad and the $\beta$-casein gene is expressed at near normal levels (Liu et al. 1997). Similarly, inactivation of the inhibin $\beta B$ gene inhibits late stages of functional epithelial differentiation, but the expression of $\beta$-casein is unaffected (Robinson and Hennighausen 1997). Thus, we suggest that $C / E B P \beta$ is involved in stages prior to $P R L$ or inhibin $\beta B$ requirement and functions independently of the JAK2/Stat5a pathway. The absence of the receptors for estrogen and progesterone has a more profound consequence on mammary development. ER deficiency leads to severely impaired ductal development, and retarded alveolar development was observed in PR-null mice (Boccinfuso and Korach 1997; Cunha et al. 1997). It has been shown that $C$ /EBP $\beta$ can partici pate in estrogen signal ing by mediating repression of the interl eukin- 6 promoter in breast tumor derived M CF-7 cells (Stein and Yang 1995; Galien et al. 1996). Thus, compromised estrogen responses may be in part responsible for the observed phenotype of $\mathrm{C} / \mathrm{EBP} \beta$-deficient mammary epithelial cells.

In $C / E B P \beta$ mutant mice at term expression of the WAP, WDNM 1 , or $\beta$-casein genes was virtually undetectable, suggesting that they are targets for $C / E B P \beta$. We suggest that the $\beta$-casein gene is a direct target, and the WAP gene is controlled indirectly. The promoter of the $\beta$-casein gene, a major milk protein, contai ns four C/EBP binding sites that are required for basal and hormonedependent activation of the promoter in tissue culture (Doppler et al. 1995; Raught et al. 1995). Our in vivo results corroborate the cell culture results. Based on a sequence analysis no $\mathrm{C} / \mathrm{EBP}$ binding site has been identified in $4 \mathrm{~kb}$ of WAP gene promoter sequence, and it is possible that $C / E B P \beta$-deficiency imposes an early block on epithelial cell differentiation, which in turn could explain the lack of expression of WAP and WDNM 1. However, because of the relaxed sequence specificity of C/EBP proteins, direct WAP and WDNM 1 promoter analysis will be required to address the role of C/EBP proteins in the activation of these genes.

The true target genes that convey the transcriptional signal from C/EBP $\beta$ are still elusive. We have demonstrated reduced proliferation potential of mammary epithelial cells as early as day 6 of gestation. The reduced number of epithelial cells in term mammary tissue re sults from an overall reduced cell proliferation, particularly in early pregnancy, the phase of most rapid growth, and slightly elevated apoptosis rates in the second half of pregnancy. This observation may reflect an inability of the $C / E B P \beta$-deficient epithelium to respond efficiently to signals mediated by the above-mentioned homones. $M$ any cell culture models have linked members of the C/EBP family to proliferation, growth arrest, or apoptosis (for review, see Johnson and Williams 1994). This notion raises the possibility that $C / E B P \beta$-deficiency imposes an early block on epithelial cell differentiation, such that the stage at which milk protein genes are expressed is never reached and the lack of milk production is only an indirect effect of the mutation. This question can be addressed in the future by the development of a mouse mutant with a targeted conditional deletion of the $\mathrm{C} / \mathrm{EBP} \beta$ gene at different stages of pregnancy. 


\section{Materials and methods}

Mice

The C/EBP $\beta$-deficient mice generated by homologous recombination have been described previously (Sterneck et al. 1997). Mice of mixed genetic strain background (129/Sv $\times$ C 57BL/6) or pure $129 / \mathrm{Sv}$ strain background were used for experiments. No strain-specific differences were noted. Therefore, the strain backgrounds are not further specified in Results. Homozygous mutants and control subjects were littermates derived from intercrossing hemizygous parents. The mice were housed and bred in a specific pathogen-free facility with a 12-hr light cycle starting at 7:00 a.m. and chow and water ad libidum. Procedures were conducted in compliance with the guidelines of the Animals Studies Committee of the $\mathrm{N}$ ational Cancer Institute and the N ational Institute of Diabetes, Digestive and Kidney Diseases. For pregnancy stages of mammary glands the mice were mated and inspected for the presence of vaginal plugs in the mornings. The day of the vaginal plug was counted as day 0 of pregnancy.

\section{Whole mounts and histology}

The first inguinal glands were dissected at the indicated times of devel opment and spread on a glass slide. After fixation for 2-4 hr in Carnoy's fixative the tissues were hydrated and stained in carmine alum overnight as previously described (Robinson et al. 1995). They were dehydrated, cleared in xylene, and mounted. After pictures were taken on a stereomicroscope the samples were embedded in paraffin and sectioned at $5 \mu \mathrm{m}$ and stained with hematoxylin and eosin according to standard procedures.

\section{Mammary transplants}

Mammary epithelia were transplanted into cleared mammary fat pads as previously described (Robinson and Hennighausen 1997). For donors of mixed genetic background, the host animals were $F_{1}$ hybrid offspring of $129 / \mathrm{Sv}$ and C57BL/ 6 parents. For clearing of the endogenous mammary epithelium, the tissue between the nipple and the lymph node was excised from 3week-old female mice and a piece of mammary tissue from a mature virgin donor was implanted into the center of the remaining fat pad. The transplanted mammary glands were harvested from virgin mice 4 or 8 weeks after the operation. To obtain transplanted tissues at term, the hosts were mated 8 weeks after they received the transplant and the mammary glands were harvested the morning after delivery. For transplantations of the entire fat pad 3-week-old mice were used as described before (Robinson and Hennighausen 1997). The endogenous inguinal fat pad of wild-type mice was removed. Fat pads of wild-type and $C / E B P \beta$-deficient mice with an epithelial transplant from a wild-type mouse were implanted on opposite sides and attached to the peritoneum by sutures. The transplants were harvested from virgin mice after 8 weeks or from term animals as described above.

\section{Ovary transplants}

Ovary transplants were performed as described (Sterneck et al. 1997). Briefly, 3- to 4-week-old donor and recipient littermates were anesthetized with avertin. The ovarian fat pads were moved outside through a small incision through the skin. The bursa was opened at one end and the ovary was teased out and placed into PBS at $37^{\circ} \mathrm{C}$. The bursa was hel d open with tweezers and the replacement ovary was pushed into the bursa. The ovary, oviduct, and uterus were then placed back into the body cavity, making sure that the ovary was fully inserted inside the bursa. The skin incisions were closed with 9-mm wound clips and the mice were given appropriate postoperative care. Two weeks postsurgery the mice were mated.

\section{RNA isolation and Northern blots}

RNA from the first inguinal glands was prepared by the acid guanidinium thiocyanate-phenol-chloroform method (ChomCzynski and Sacchi 1987) or with RN A STAT-60 reagent (TELTEST "B," Friendswood, TX) according to the manufacturer's protocol. Twenty micrograms of total RNA was separated in $1.5 \%$ formaldehyde gels and blotted on GeneScreen membranes. Expression of milk protein RNA was analyzed using specific oligonucleotides as previously described (Robinson et al. 1996). Expression of C/EBP genes was analyzed with a DNA probe to the $3^{\prime}$ UTR of the rat C/EBP $\beta$ gene (Sterneck et al. 1997) and an 850-bp Smal-HindlI fragment representing the $3^{\prime}$ UTR of the mouse C/EBP $\alpha$ gene. The probe for keratin 18 was a 1.1-kb EcoRI cDN A fragment (Singer et al. 1986). PPAR 2 was detected by a 1.5-kb Sacl fragment spanning the coding region of the PPAR 2 cDNA [kindly provided by Jeffrey Gimble, Oklahoma University (Gimble et al. 1996)]. Oligonucleotides were hybridized at $55^{\circ} \mathrm{C}$ and CDNA probes were hybridized at $65^{\circ} \mathrm{C}$.

\section{Cell proliferation and cell death assays}

Two hours before sacrifice, mice were injected with $20 \mu \mathrm{l} / \mathrm{g}$ of body weight of cell labeling reagent (Amersham cell proliferation kit). Mammary glands were prepared and fixed in Tellyesniczky's solution for $4 \mathrm{hr}$. The tissues were embedded in paraffin. For detection of incorporated BrdU 5- $\mu$ m sections were processed according to the manufacturer's instructions (Amersham Life Science). On neighboring sections from the same samples, apoptotic cells were detected by TUNEL assay as described by Humphreys et al. (Humphreys et al. 1996). Between 6000 and 9000 cells were counted from six to eight different sections of a sample and the means were cal culated.

\section{Acknowledgments}

We thank Hanhua Chen for excellent help with histological procedures; L. Sewell, B. Shankle, and D. Swing for expert technical assistance; and A.J. Lincoln for providing DNA from the mouse $\mathrm{C} / \mathrm{EBP} \alpha$ genomic locus. Research was sponsored in part by the $\mathrm{N}$ ational Cancer Institute, Department of Health and Human Services, under contract with Advanced BioScience Laboratories, Inc.

The publication costs of this article were defrayed in part by payment of page charges. This article must therefore be hereby marked "advertisement" in accordance with 18 USC section 1734 solely to indicate this fact.

\section{References}

Boccinfuso, W.P. and K.S. Korach. 1997. M ammary gland development and tumorigenesis in estrogen receptor knockout mice. J. Mammary Gland Biol. Neoplasia 2: 323-334.

Cao, Z., R.M. Umek, and S.L. McKnight. 1991. Regulated expression of three $\mathrm{C} / \mathrm{EBP}$ isoforms during adi pose conversion of 3T 3-L1 cells. Genes \& Dev. 5: 1538-1552.

Chen, H., B. Lin, C.L. Chen, P.F. Johnson, and J.Y. Chou. 1995. Role of the transcription factor C/EBP beta in expression of a rat pregnancy-specific glycoprotein gene. DNA Cell Biol. 14: $681-688$. 
Chomczynski, P. and N. Sacchi. 1987. Single step method of RNA isolation by acid guanidinium thiocyanate-phenolchloroform extraction. Anal. Biochem. 162: 156-159.

Cooper, C., A. Henderson, S. Artandi, N. Avitahl, and K. Calame. 1995. Ig/EBP (C/EBP gamma) is a transdominant negative inhibitor of C/EBP family transcriptional activators. Nucleic Acids Res. 23: 4371-4377.

Cunha, G.R., P. Young, Y.K. Hom, P.S. Cooke, J.A. Taylor, and D.B. Lubahn. 1997. Elucidation of a role for stromal steroid hormone receptors in mammary gland growth and development using tissue recombinants. J. Mammary Gland Biol. Neoplasia 2: 393-402.

Daniel, C.W. and G.B. Sil berstein. 1987. Postnatal development of the rodent mammary gland. In The mammary gland: De velopment, regulation and function (ed. M.C. N eville and C.W. Daniel), pp. 3-36. Plenum, N ew York, NY.

DeOme, K.B., L.J. Faulkin, Jr., H.A. Bern, and P.E. Blair. 1959. Development of mammary tumors from hyperplastic alveoIar nodules transplanted into gland-free mammary fat pads of female C3H mice. Cancer Res. 19: 515-520.

Doppler, W., T. Welte, and S. Philipp. 1995. CCAAT/enhancerbinding protein isoforms beta and delta are expressed in mammary epithelial cells and bind to multiple sites in the beta-casein gene promoter. J. Biol. Chem. 270: 17962-17969.

Fantl, V., G. Stamp, A. Andrews et al. 1995. Mice lacking cyclin D1 are smaller and show defects in eye and mammary gland development. Genes \& Dev. 9: 2364-2372.

Galien, R., H.F. Evans, and T. Garcia. 1996. Involvement of CCAAT/enhancer-binding protein and nuclear factor-kappa $B$ binding sites in interleukin- 6 promoter inhibition by estrogens. Mol. Endocrinol. 10: 713-722.

Gigliotti, A.P. and J.W. DeWille. 1998. Lactation status influences expression of CCAAT/enhancer binding protein isoform mRNA in the mouse mammary gland. J. Cell. Physiol. 174: 232-239.

Gimble, J.M., C.E. Robinson, X. Wu, K.A. Kelly, B.R. Rodriguez, S.A. Kliewer, J.M. Lehmann, and D.C. Morris. 1996. Peroxisome proliferator-activated receptor-gamma activation by thiazolidinediones induces adipogenesis in bone marrow stromal cells. Mol. Pharmacol. 50: 1087-1094.

Hennighausen, L. and G.W. Robinson. 1998. Think globally, act locally: The making of a mouse mammary gland. Genes \& Dev. 12: 449-455.

Humphreys, R.C., M. Krajewska, S. Krnacik, R. Jaeger, H. Weiher, S. Krajewski, J.C. Reed, and J.M. Rosen. 1996. A poptosis in the terminal endbud of the murine mammary gland: A mechanism of ductal morphogenesis. Development 122: 4013-4022.

Humphreys, R.C., J. Lydon, B.W. O'Malley, and J.M. Rosen. 1997. Mammary gland development is mediated by both stromal and epithelial progesterone receptors. Mol. Endocrinol. 11: 801-811.

Imagawa, W., J. Yang, R. Guzman, and S. N andi. 1994. Control of mammary gland devel opment. In The physiology of reproduction. 2nd ed. (ed. E. Knobil and J.D. N eill), pp. 1033-1059. Raven, N ew York, NY.

Johnson, P.F. and S.C. Williams. 1994. CCAAT/enhancer binding (C/EBP) proteins. In Liver gene expression (ed. M. Yaniv and F. Tronche), pp. 231-258. R.G. Landes, Austin, TX.

Liu, X., G.W. Robinson, K.U. Wagner, L. Garrett, A. WynshawBoris, and L. Hennighausen. 1997. Stat5a is mandatory for adult mammary gland devel opment and lactogenesis. Genes \& Dev. 11: 179-186.

Lydon, J.P., F.J. DeM ayo, C.R. Funk et al. 1995. Mice lacking progesterone receptor exhibit pleiotropic reproductive abnormalities. Genes \& Dev. 9: 2266-2278.
O'Rourke, J., R. Yuan, and J. DeWille. 1997. CCAAT/enhancerbinding protein-delta (C/EBP-delta) is induced in growth-arrested mouse mammary epithelial cells. J. Biol. Chem. 272: 6291-6296.

Ormandy, C.J., A. Camus, J. Barra, D. Damotte, B. Lucas, H. Buteau, M. Edery, N. Brousse, C. Babinet, N. Binart, and P.A. Kelly. 1997. Null mutation of the prolactin receptor gene produces multiple reproductive defects in the mouse. Genes \& Dev. 11: 167-177.

Raught, B., W.S. Liao, and J.M. Rosen. 1995. Developmentally and hormonally regulated CCAAT/enhancer-binding protein isoforms influence beta-casein gene expression. Mol. Endocrinol. 9: 1223-1232.

Raught, B., A.C. Gingras, A. James, D. Medina, N. Sonenberg, and J.M. Rosen. 1996. Expression of a translationally regulated, dominant-negative CCAAT/enhancer-binding protein beta isoform and up-regulation of the eukaryotic translation initiation factor 2al pha are correl ated with neoplastic transformation of mammary epithelial cells. Cancer Res. 56: 4382-4386.

Robinson, G.W. and L. Hennighausen. 1997. Inhibins and activins regulate mammary epithelial cell differentiation through mesenchymal-epithelial interactions. Development 124: 2701-2708.

Robinson, G.W., R.A. McKnight, G.H. Smith, and L. Hennighausen. 1995. Mammary epithelial cells undergo secretory differentiation in cycling virgins but require pregnancy for the establishment of terminal differentiation. Development 121: 2079-2090.

Robinson, G.W., G.H. Smith, D. Gallahan, A. Zimmer, P.A. Furth, and L. Hennighausen. 1996. Understanding mammary gland development through the imbal anced expression of growth regulators. Dev. Dyn. 206: 159-168.

Roman, C., J.S. Platero, J. Shuman, and K. Calame. 1990. Ig/ EBP-1: A ubiquitously expressed immunogl obulin enhancer binding protein that is similar to C/EBP and heterodimerizes with C/EBP. Genes \& Dev. 4: 1404-1415.

Schaapveld, R.Q.J., J.T.G. Schepens, G.W. Robinson, J. Attema, F.T.T.J. Oerlemans, J.A.M. Fransen, M. Streuli, B. Wieringa, L. Hennighausen, and W.J.A.J. Hendriks. 1997. Impaired mammary gland development and function in mice lacking LAR receptor-like tyrosine phosphatase activity. Dev. Biol. 188: 134-146.

Screpanti, I., L. Romani, P. M usiani, A. Modesti, E. Fattori, D. Lazzaro, C. Sellitto, S. Scarpa, D. Bellavia et al. 1995. Lymphoproliferative disorder and imbal anced T-hel per response in C/EBP beta-deficient mice. EMBO J. 14: 1932-1941.

Sicinski, P., J.L. Donaher, S.B. Parker, T. Li, A. Fazeli, H. Gardner, S.Z. Haslam, R.T. Bronson, S.J. Elledge, and R.A. Weinberg. 1995. Cyclin D1 provides a link between development and oncogenesis in the retina and breast. Cell 82: 621-630.

Singer, P.A., K. Trevor, and R.G. Oshima. 1986. Molecular cloning and characterization of the Endo B cytokeratin expressed in preimplantation mouse embryos. J. Biol. Chem. 261: 538547.

Stein, B. and M.X. Yang. 1995. Repression of the interleukin-6 promoter by estrogen receptor is mediated by NF-kappa B and C/EBP beta. Mol. Cell. Biol. 15: 4971-4979.

Sterneck, E., L. Tessarollo, and P.F. Johnson. 1997. An essential role for C/EBPbeta in female reproduction. Genes \& Dev. 11: 2153-2162.

Tanaka, T., S. Akira, K. Yoshida, M. U memoto, Y. Yoneda, N. Shirafuji, H. Fujiwara, S. Suematsu, N. Yoshida, and T. Kishimoto. 1995. Targeted disruption of the NF-IL6 gene discloses its essential role in bacteria killing and tumor cytotoxicity by macrophages. Cell $\mathbf{8 0}$ : 353-361. 


\section{Robinson et al.}

Tanaka, T., N. Yoshida, T. Kishimoto, and S. Akira. 1997. Defective adipocyte differentiation in mice lacking the C/EBP $\beta$ and/or C/EBP gene. EMBO J. 16: 7432-7443.

Topper, Y.J. and C.S. Freeman. 1980. Multiple hormone interactions in the devel opmental biology of the mammary gland. Physiol. Rev. 60: 1049-1056.

Toscani, A., R.V. M ettus, R. Coupland, H. Simpkins, J. Litvin, J. Orth, K.S. Hatton, and E.P. Reddy. 1997. Arrest of spermiogeneis and defective breast development in mice lacking Amyb. Nature 386: 713-717.

Wang, N.D., M.J. Finegold, A. Bradley, C.N. Ou, S.V. Abdelsayed, M.D. Wilde, L.R. Taylor, D.R. Wilson, and G.J. Darlington. 1995. Impaired energy homeostasis in C/EBP al pha knockout mice. Science 269: 1108-1112.

Wegner, M., Z. Cao, and M.G. Rosenfeld. 1992. Cal cium-regulated phosphorylation within the leucine zipper of C/EBP beta. Science 256: 370-373.

Williams, S.C., C.A. Cantwell, and P.F. Johnson. 1991. A family of C/EBP-related proteins capable of forming covalently linked leucine zi pper dimers in vitro. Genes \& Dev. 5: 15531567.

Yamanaka, R., C. Barlow, J. Lekstrom-Himes, L.H. Castilla, P.P. Liu, M. Eckhaus, T. Decker, A. Wynshaw-Boris, and K.G. Xanthopoulos. 1997a. Impaired granulopoiesis, myelodysplasia, and early lethality in CCAAT/enhancer binding protein epsilon-deficient mice. Proc. Natl. Acad. Sci. 94: 1318713192.

Yamanaka, R., G.D. Kim, H.S. Radomska, J. Lekstrom-Hines, L.T. Smith, P. Antonson, D.G. Tenen, and K.G. Xanthopoulos. 1997b. CCAAT/enhancer binding protein epsilon is preferentially up-regulated during granulocytic differentiation and its functional versatility is determined by alternative use of promoters and differential splicing. Proc. Natl. Acad. Sci. 94: 6462-6467.

Zhang, D.E., P. Zhang, N.D. Wang, C.J. Hetherington, G.J. Darlington, and D.G. Tenen. 1997. Absence of granulocyte colony-stimulating factor signaling and neutrophil development in CCAAT enhancer binding protein al pha-deficient mice. Proc. Natl. Acad. Sci. 94: 569-574. 


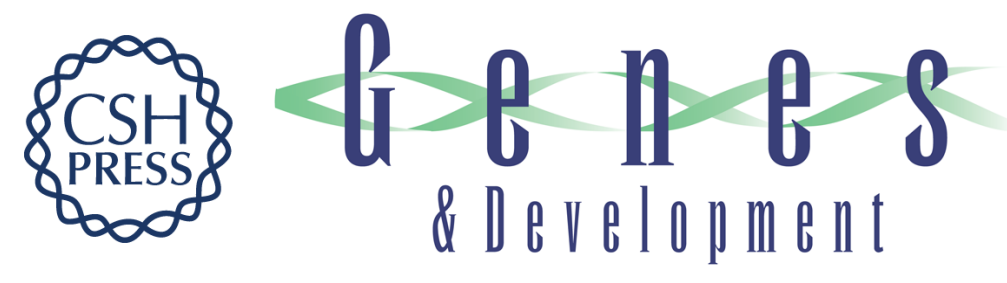

\section{The C/EBP $\beta$ transcription factor regulates epithelial cell proliferation and differentiation in the mammary gland}

Gertraud W. Robinson, Peter F. Johnson, Lothar Hennighausen, et al.

Genes Dev. 1998, 12:

Access the most recent version at doi:10.1101/gad.12.12.1907

References This article cites 40 articles, 24 of which can be accessed free at: http://genesdev.cshlp.org/content/12/12/1907.full.html\#ref-list-1

License

Email Alerting

Receive free email alerts when new articles cite this article - sign up in the box at the top Service right corner of the article or click here.

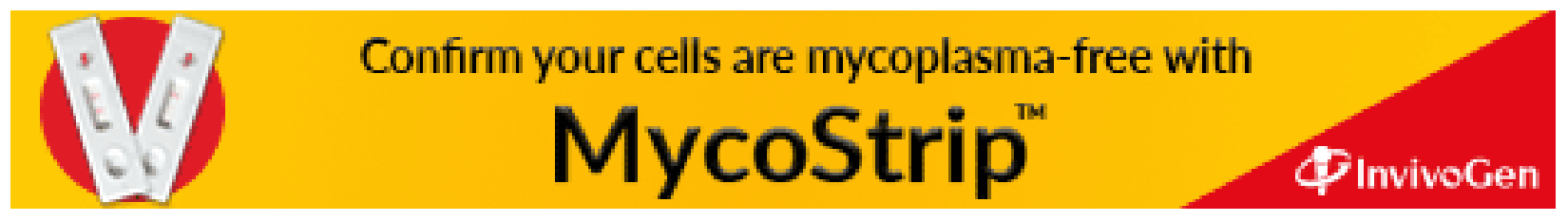

